IDS WORKING PAPER

Volume 2011 No 385

Poverty and Violent Conflict: A

Micro-Level Perspective on the

Causes and Duration of Warfare

Patricia Justino

December 2011 
The Conflict, Violence and Development Research Cluster is part of the Vulnerability and Poverty Reduction Team at the Institute of Development Studies. The Cluster's main focus is to develop new insights into how people in contexts of conflict and violence live and interact, and what institutions help (or hinder) them. We aim to use our research findings to inform, identify and develop policies and practices that will strengthen people's own efforts to survive and make a living.

Email: conflict@ids.ac.uk

Web: www.ids.ac.uk/go/research-teams/vulnerability-and-poverty-reduction-team/researchthemes/conflict

\section{CVD WP6}

Poverty and Violent Conflict: A Micro-Level Perspective on the Causes and Duration of Warfare

Patricia Justino

IDS Working Paper 385

First published by Microcon as Working Paper 6 in 2008/9

Second edition reprinted as HiCN Working Paper 46 in 2008

Third edition reprinted as IDS Working Paper 385 December 2011

(c) Institute of Development Studies 2011

ISSN: 1353-6141 ISBN: 978-1-78118-041-9

A catalogue record for this publication is available from the British Library.

All rights reserved. Reproduction, copy, transmission, or translation of any part of this publication

may be made only under the following conditions:

- with the prior permission of the publisher; or

- with a licence from the Copyright Licensing Agency Ltd., 90 Tottenham Court Road, London

W1P 9HE, UK,

or from another national licensing agency; or

- under the terms set out below.

This publication is copyright, but may be reproduced by any method without fee for teaching or nonprofit purposes, but not for resale. Formal permission is required for all such uses, but normally will be granted immediately. For copying in any other circumstances, or for reuse in other publications, or for translation or adaptation, prior written permission must be obtained from the publisher and a fee may be payable.

Available from:

Communications Unit, Institute of Development Studies, Brighton BN1 9RE, UK Tel: +44 (0) 1273915637

Fax: +44 (0) 1273621202

E-mail: bookshop@ids.ac.uk

Web: www.ids.ac.uk/ids/bookshop

IDS is a charitable company limited by guarantee and registered in England (No. 877338) 


\title{
Poverty and Violent Conflict: A Micro-Level Perspective on the Causes and Duration of Warfare
}

\author{
Patricia Justino
}

\section{Summary}

This paper discusses how endogenous mechanisms linking processes of violent conflict and the economic well-being of individuals and households in combat areas provide valuable micro foundations to the ongoing debate on the causes and duration of armed conflict. Notably, the endogenous relationship between conflict processes and household economic status leads to the emergence of symbiotic associations between armed groups and households living in areas they control that affect substantially the probability of a conflict starting and its effectiveness thereafter. Households in conflict areas draw on local armed groups to protect their economic status when anticipating violence and during the conflict, while armed groups make use of different levels of (either reluctant or voluntary) participation, support and cooperation from local populations to advance their strategic objectives at the onset and throughout the conflict. The level of household participation at the start and during the conflict is a function of two interdependent variables, namely household vulnerability to poverty and household vulnerability to violence. The poorer the household is at the start of the conflict, the higher is the probability of the household participating and supporting an armed group. The higher the risk of violence, the higher is the probability of the household participating and supporting armed groups. The interaction between these two variables varies with the conflict itself and is defined by the direct and indirect effects of conflict-induced violence on the economic behaviour and decisions of households in combat areas.

Keywords: household poverty; household welfare; causes of armed conflict; duration of conflict; micro-foundations of conflict.

Patricia Justino is a Research Fellow at the Institute of Development Studies, specialising in applied microeconomics. Her current research work focuses on the impact of violence and conflict on household welfare, the microfoundations of violent conflict and the implications of violence for economic development. She is the Director of MICROCON and co-founder and co-director of the Households in Conflict Network. Since June 2010, Patricia convenes the IDS Vulnerability and Poverty Reduction team research cluster on Conflict, Violence and Development. 


\section{Contents}

Summary, keywords, author notes 3

Acknowledgements 5

$\begin{array}{ll}\text { Introduction and scope of the paper } & 6\end{array}$

$1 \quad$ Impact of household poverty on the outbreak of violent conflict $\quad 7$

$2 \quad$ Impact of violent conflict on household economic status 9

2.1 Direct impact of violence: household composition, wealth and residence 10

2.2 Indirect impact of violence on local markets 11

$\begin{array}{ll}2.3 & \text { Indirect impact of violence on community relations } \\ & 11\end{array}$

$\begin{array}{ll}2.4 & \text { Indirect impact of violence on political institutions } \\ & 12\end{array}$

$\begin{array}{ll}2.5 & \text { Indirect impact of violence on economic growth and distribution }\end{array}$

3 Household adaptation strategies and the duration of violent conflicts 13

$4 \quad$ Framework for the analysis of individual and household participation in armed groups

$5 \quad$ Conclusion and implications 17

$\begin{array}{lr}\text { References } & 19\end{array}$

Figures

Figure 2.1 Endogenous relationship between violent conflict and household poverty

Tables

Table 4.1 Participation in armed groups 


\section{Acknowledgements}

I would like to thank Armando Barrientos, Tony Addison, two anonymous referees and the JPR editor, Patrick Regan, for extensive comments on previous drafts of the paper. I am also grateful to participants of the expert group meeting on Post-Conflict Recovery and Economic Insecurity at the UNDP in New York, 30 Nov 2007, Maeve Powlick in particular, and to participants of the 2008 MICROCON annual meeting in Bulgaria and the 2008 MICROCON summer school in Olympia, Greece, for comments and suggestions. Bruce Guenther has provided excellent research assistance. A number of ideas addressed in this paper draw on discussions with Tilman Brück and Philip Verwimp before and since the foundation of the Households in Conflict Network. The paper has received funding from the European Commission as part of the MICROCON Integrated Project (www.microconflict.eu). The views expressed in this paper are those of the author alone and do not necessarily reflect those of the European Commission and its members.

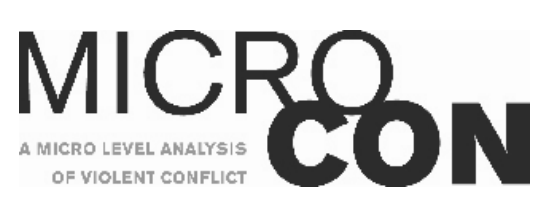

This paper previously appeared as MICROCON Research Working Paper 6 in 2008, updated January 2009, and as HiCN Working Paper 46 in May 2008. 


\section{Introduction and scope of the paper}

Empirical analyses of civil war point to low-per capita income as one of the most robust explanations for the outbreak and duration of violent internal conflict (Collier et al. 2003; Collier, Hoeffler and Söderbom 2004; Collier and Hoeffler 1998, 2004; Do and lyer 2007; Doyle and Sambanis 2006; Elbadawi and Sambanis 2000, 2002; Fearon 2004; Fearon and Laitin 2003; Hegre and Sambanis 2006; Murshed and Gates 2005; Stewart and Fitzgerald 2001; World Bank 2005). Although this evidence rests on implicit assumptions on what makes low national or sub-national incomes a condition for violent conflict - association with weak state institutions, large group-based grievances and low economic opportunity costs of fighting - existing research offers only limited systematic accounts of the micro-level channels through which low incomes amongst a large fraction of individuals in society affect the viability of violent conflicts. This paper addresses this gap in the literature by exploring analytically and theoretically internal characteristics of conflict processes rooted in endogenous interactions between violence and the economic behaviour of ordinary people living in areas of armed conflict that may provide valuable though overlooked micro foundations to recent debates on the causes and duration of civil wars.

The importance of population support for the success of armed rebellions is well-recognised in the literature on civil wars (see review in Weinstein 2007). What is less well understood is how micro-level economic factors and decisions influence the start of violent conflicts, and how those processes change and evolve throughout the conflict itself as the economic effects of violence shape the behaviour of individuals and households in combat areas and that of surrounding institutions. At a fundamental level, the outbreak and viability of violent armed conflicts is closely linked to the conduct and motivations, not only of rebel groups, elites and the state army, but also ordinary members of society living in (potential) combat areas. These people must adapt to strenuous circumstances to survive. They take on available opportunities (which may or may not include fighting, looting and denunciation of former friends and neighbours), adopt forms of livelihoods that may lead to severe poverty traps but avoid famine (or not), join in informal exchange and employment markets (which may or may not include illegal activities), form social and political alliances in new areas of residence that may allow economic survival or may lead to a life of crime and violence (or both), and take on different social and political identities in response to their anticipated exposure to violence before the conflict, their actual exposure to violence during the conflict, the efficacy of mobilisation by different factions before and during the conflict and changes in territorial and population control by state armies and rebel groups (see Kalyvas 2007; Kalyvas and Kocher 2007; Petersen 2001; Wood 2003).

Part of this process of adaptation to violence is the establishment of relationships between armed groups and individuals and households living in areas they control or wish to control. Rarely will a civil war start or progress without opposing factions securing significant population support (see Azam 2006; Weinstein 2007). In addition, ordinary citizens draw on armed groups to protect their economic status when anticipating outbreaks of violence, and during conflict, when the costs of non-participation may signify poverty and destitution (see Kalyvas and Kocher 2007). Armed groups in turn make use of different levels of support from local populations to advance their strategic objectives. This symbiotic association between armed groups and populations in combat areas will affect substantially the probability of a conflict starting and its effectiveness thereafter.

The main objective of this paper is to provide a theoretical and analytical framework to understand processes leading to this association, and how those processes change throughout the conflict itself as a response to the effects of violence on the economic status of people living in conflict areas. The paper concentrates on processes of violence that result from 'armed combat within the boundaries of a recognised sovereign entity between parties 
subject to a common authority at the outset of the hostilities' (Kalyvas 2007: 17), with a particular emphasis on insurgent civil wars. ${ }^{1}$ Throughout the paper, the term 'household' designates a group of non-state actors that share common living arrangements. As regularly experienced in conflict settings, households may include both civilian and non-civilian actors, where fighters may be recruited (voluntary or by force) by either the state military or rebel groups. ${ }^{2}$ The paper focuses both on decisions taken by the household as an economic unit and by individual household members in their different roles during the course of armed conflict. The typical household being considered is a rural household living in areas disputed by armed groups with members employed mostly in agricultural activities, or households living in small towns in rural areas of dispute. Household participation is defined as encompassing the provision of members as fighters in rebel groups or the state army, as well as the supply of material support, shelter and information to any of the fighting groups. Deliberate non-denunciation of activities of armed groups is also considered to be a form of participation. ${ }^{3}$

The paper is organised as follows. The next section reviews the literature on economic motivations for individual and household participation in armed groups. The following two sections are concerned with changes in household participation as a function of the direct and indirect effects of violent conflict. I first explore the channels through which conflictrelated violence affects the economic status of households and individuals in conflict areas, by drawing on recently emerging empirical literature on the micro-level consequences of violent conflicts. Subsequently I discuss how economic effects of violence may shape individual and household adaptation strategies, notably the participation in and support for armed groups. I propose then a theoretical framework to understand the relationship between households in conflict areas and armed groups as a function of two household-level variables responsible for the capacity of households to adapt to the effects of violence, namely their vulnerability to poverty and vulnerability to violence. I put forward several theoretical hypotheses on how the levels of household vulnerability to poverty and violence affect household participation and support of armed groups, and hence the sustainability and duration of warfare. The concluding section discusses some theoretical, empirical and policy implications of this analysis.

\section{Impact of household poverty on the outbreak of violent conflict}

The decision to start a civil war, or any other form of violent conflict, depends on several factors including external military and financial intervention, the level of technology and resources available to each armed group, the intensity of their ideological beliefs and the relative strength of state presence in key areas in the country. ${ }^{4}$ But it also depends crucially on internal characteristics of conflict processes such as the participation and support of local

Other types of conflict are certainly likely to affect and be affected by the actions and behaviour of poor households, albeit through different mechanisms. For the economic analysis other types of conflict see Becker (1967) on crime, Justino (2006) on communal riots and industrial disputes, Krueger and Malečková (2003) on suicide bombers, Bueno de Mesquita (2005) on individual participation in terrorist organisations and Tolman and Raphael (2000) on domestic violence.

2 The analysis in this paper does not distinguish between participation in rebel groups or in the state army as reasons for participation are unlikely to vary much across these two categories. This argument is supported by empirical evidence presented in Humphreys and Weinstein (2008).

3 For more detailed distinctions between several levels of participation by individuals in insurrections see Petersen (2001).

This literature is reviewed extensively in Weinstein (2007) and Blattman and Miguel (2010). The role of natural resources such as oil, minerals and precious stones in the outbreak of civil wars is particularly well documented. Humphreys $(2005)$ and Ross $(2004,2006)$ provide critical reviews of this literature. 
populations, not only as fighters, but also in the provision of material support, shelter and information (see Kalyvas 2007; Petersen 2001; Weinstein 2007). Although most of the research work on individual motivations to participate in armed groups is concerned with the decision to become a fighter, ${ }^{5}$ this literature also offers significant insights as to why individuals and their families may support the activities of armed groups through other means, either voluntary or reluctantly.

Many individuals and their families are forced into forms of involuntary participation in armed groups through coercion and abduction (Blattman and Annan 2007; Humphreys and Weinstein 2008), fear of violence (Kalyvas 2007; Kalyvas and Kocher 2007) and due to the strength of peer-pressure and community norms and sanction (Petersen 2001; Pinchotti and Verwimp 2007; Scott 1976; Verwimp 2005). Some participate due to several socio-emotional motivations, including 'pleasure of agency' (Wood 2003), ideological and cultural identification with the armed group, revenge against the opposed group (including the state), grief, anger and pride (see Goodwin 2001; Wood 2003; Petersen 2001). And others participate to voice group or class discontent and accumulated grievances (Gurr 1970; Horowitz 1985; Paige 1975; Scott 1976; Richards 1996; Wickham-Crowley 1992). Economic reasons may overlap with these motivations, or may provide a separate case for why individuals and households support and participate in armed groups. ${ }^{6}$

This has been widely recognised in the literature on individual motivations for participation in collective violence. This literature, dominated by the work of Mancur Olson (1965), attributes participation in collective action to the presence of selective incentives. Monetary incentives, in particular, have given rise to extensive research in the last decade. ${ }^{7}$ Despite the potentially high individual costs (of death, injury and imprisonment), many may choose to participate in acts of violence and support armed groups because they have a lot to gain from the conflict in terms of improved socio-economic opportunities, looting and the appropriation of valuable assets (Grossman 2002; Hirshleifer 2001; Keen 1998, 2005).

Recent literature, following the accumulation of empirical evidence on economic motivations for participation in armed conflict, has however shown that material benefits accrued to rank and file soldiers seem to be generally at best sufficient to satisfy basic needs as larger profits tend to remain within the leadership of the armed group (Humphreys and Weinstein 2008; Verwimp 2005). Many support and cooperate (voluntarily or involuntarily) with armed groups not just for opportunistic reasons, but rather to guarantee survival and the fulfilment of basic economic needs (Humphreys and Weinstein 2008; Richards 1996). In particular, levels of poverty may drive individuals into conflict as some may gain more from being fighters than from peacetime activities, notably when productive activities are scarce, unemployment is high and returns from agriculture work are low (Collier and Hoeffler 1998; Grossman 2002; Walter 2004).

The fulfilment of basic needs and access to livelihoods is closely related to another reason for participation that has remained elusive in the literature, notably the fact that, in many circumstances, people simply cannot afford to stay out because non-participation is very costly. This argument has recently put forward recently by Kalyvas and Kocher (2007: 183): 'individuals may participate in rebellion not in spite of risk but in order to better manage it'. Although participation yields high personal costs, staying out can be as much of a risk, as non-participation increases the danger of being identified with the other side. In this case, armed groups may offer protection from indiscriminate violence from opposing factions, as

Blattman and Miguel (2010) and Humphreys and Weinstein (2008) review this literature.

It is unlikely that any of motivations surveyed above, including economic reasons, are mutually exclusive. See empirical evidence in Humphreys and Weinstein (2008).

Lichbach (1995) reviews how selective incentives have operated in a variety of forms of collective behaviour including strikes, protests, riots and rebellions. 
well as the privileged access to resources, information and skills invaluable in fighting zones (Kalyvas 2007; Kalyvas and Kocher 2007). This argument can be easily extended to issues of economic protection as the (in)ability of households to protect their economic status in conflict areas may well increase substantially the risk of non-participation (i.e. the probability of poverty and destitution). ${ }^{8}$

Armed groups periodically manipulate the perception of such costs to guarantee population support since such support will affect the effectiveness of initial outbreaks of rebellion and the strength of strategic objectives throughout the conflict. Weinstein (2007) provides evidence on how some armed groups manipulate population support to their own advantage when other resources are scarcer (see also Azam 2006). Also, road blocks, the issue of permission for access to infrastructure and markets, and restrictions of population movements are a commonly used strategy by armed groups to control populations and guarantee their support, or at least some level of cooperation.

The economic costs and motivations for individual and household (non)participation are in addition affected by the conflict process through time in response to the impact of violence on the economic status of households and on the functioning of surrounding institutions. These endogenous processes of socio-economic transformation at the household level, which originate from the conflict itself, are less well understood in the literature. ${ }^{9}$ However, they have considerable implications for how violent conflicts emerge, evolve and last because they affect significantly the organisation of violence and fighting strategies. These processes are analysed in more detail in the next two sections. The first section explores the channels through which conflict-related violence affects the economic status of households and individuals in conflict areas. The ensuing section discusses how the economic impact of violence shapes individual and household participation in and support for armed groups.

\section{Impact of violent conflict on household economic status}

Violent conflicts affect the economic status of individuals and households through the intensity and types of violence they set in motion (Kalyvas 2007). Processes of violence impact on the economic status of households through the direct and indirect transformations they entail. These channels are illustrated in Figure 2.1 (see over). ${ }^{10}$ Direct effects (represented by dotted lines) include changes in household composition due to killings, injuries and recruitment of fighters, changes in the household economic status due to the destruction of assets and livelihoods and effects caused by forced displacement and migration. Indirect effects (represented by full lines) can take place at the local (community) level or at the national level. Local indirect effects include changes in households' access to and relationship with local exchange, employment, credit and insurance markets, social relations and networks and political institutions. National-level indirect channels consist of changes in economic growth and in distributional processes that impact on household welfare. 


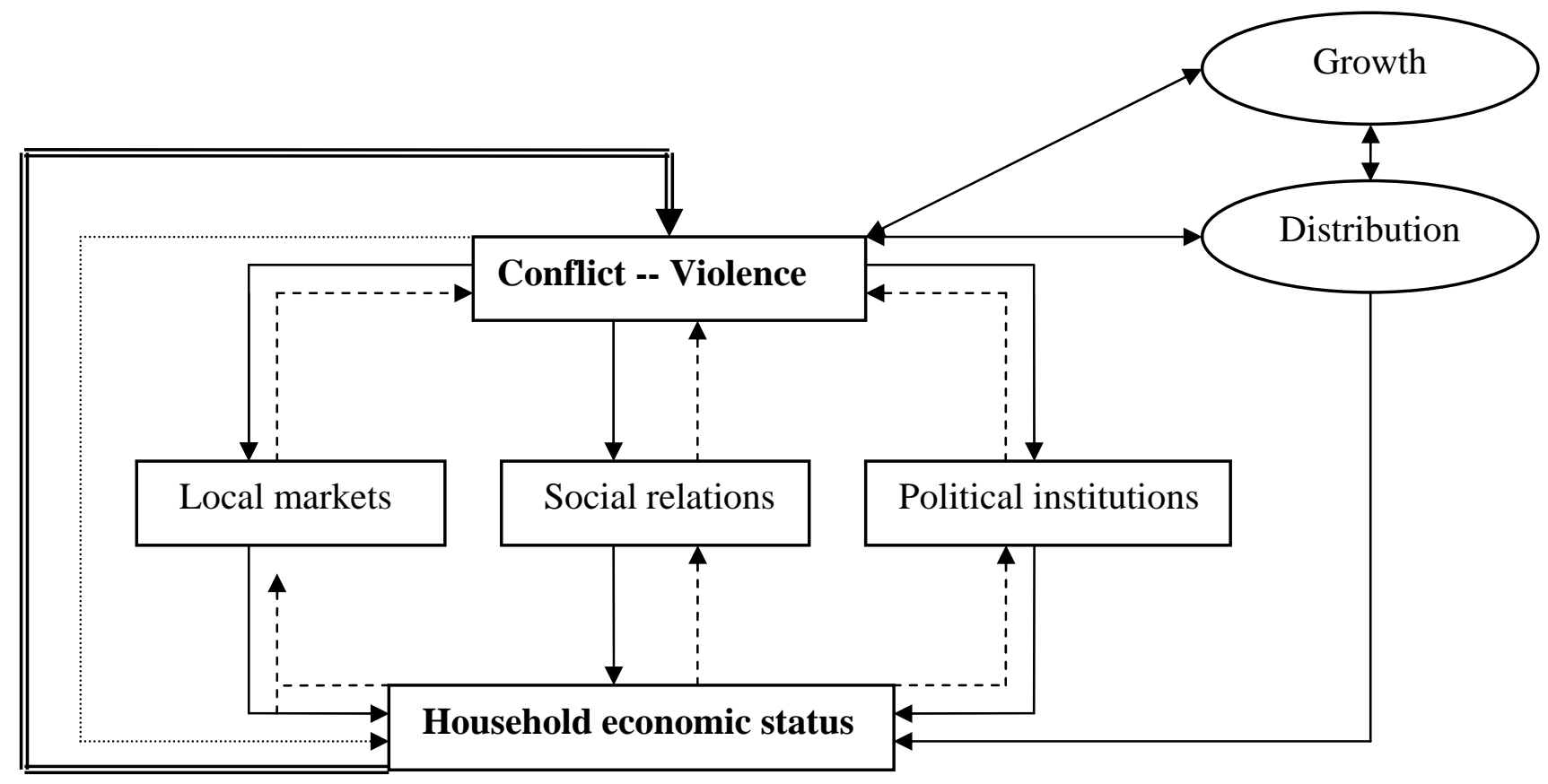

\subsection{Direct impact of violence: household composition, wealth and residence}

Civil wars in the last three decades have killed tens of millions of people, most of which civilians, and caused extensive injuries, disability and psychological damage to millions more (Ghobarah, Huth and Russett 2003; Lacina and Gleditsch 2005). During violent conflicts, assets such as houses, land, labour, utensils, cattle and livestock get lost or destroyed through heavy fighting and looting (Bundervoet and Verwimp 2005; Ibáñez and Moya 2006; Shemyakina 2006; Verpoorten 2003). Farmers often suffer the worst losses (Bundervoet and Verwimp 2005; Justino and Verwimp 2006).

These effects are made worse (and often caused by) the large population movements that accompany most violent conflicts (UNHCR, various years). Refugees from conflict areas and displaced populations are found amongst those living under the most difficult forms of socioeconomic exclusion and deprivation (see Chronic Poverty Report 2004-05). Displaced populations often struggle to find work (Engel and Ibáñez 2007; Ibáñez and Moya 2006), are less likely to work in the post-conflict period (Kondylis 2007) and exhibit lower productivity levels than those that stayed behind (Kondylis 2005).

These direct effects of violence will result for many household in considerable reductions in total income and consumption due to the loss of livelihoods and decreases in productivity and human capital when key household workers die or are incapacitated, children replace lost household labour, assets get destroyed or stolen and surviving members have to draw on existing savings to pay for medical bills or forgo employment to care for injured and disabled household members. These effects are aggravated by the breakdown of families and their social protection mechanisms caused by displacement and fighting, and may affect individual and household welfare for generations to come (see Alderman, Hoddinott and Kinsey 2006; de Walque 2004). 
The negative effects of violence may be counteracted by opportunities raised by conflict. Some will benefit from violence through looting (Keen 1998), redistribution of assets during conflict (Brockett 1990; Wood 2003), and privileged access to market and political institutions (Richards 1996). Population movements, migration in particular, may also entail some positive effects on livelihoods and the economic status of households through remittances (Justino and Shemyakina 2007; Lindley 2007). These effects are as important in understanding processes of violent conflict as the more negative effects of violence since both will have significant bearing on the sustainability of peace during the post-conflict period.

\subsection{Indirect impact of violence on local markets}

The impact of exchange and employment markets on the economic status of households operates through changes in the market price of goods sold and purchased by the household (Singh, Squire and Strauss 1986). The impact of insurance and credit markets takes place through changes in savings, and hence potential investment (Rosenzweig and Wolpin 1993). Empirical evidence on the operation of these mechanisms during armed conflict is scarce and contradictory (see Azam, Collier and Cravinho 1994; Bundervoet 2006; Verpoorten 2005). The effect of these changes on household productive decisions is even more unclear as other factors must be taken in consideration, notably increases in transaction costs caused by difficulties in accessing exchange markets when roads, train lines and other infrastructure is destroyed, adjustments to credit and insurance mechanisms and changes in access to off-farm employment. These areas of research are still in their infancy.

However, it seems clear that if households are not able to switch activities or cannot access credit, insurance or alternative employment, market shocks during armed conflict may result in significant reductions in household utility and welfare. In extreme cases, households will resort to subsistence activities, which may hinder the household's capacity to accumulate assets but may protect them against severe destitution. ${ }^{11}$

\subsection{Indirect impact of violence on community relations}

The development literature provides a good understanding of the importance of (both positive and negative) effects of social networks on the lives of the poor in peaceful settings (e.g. Fafchamps and Lund 2002; Durlauf 2006). In addition, the post-conflict literature has shown abundant evidence for the importance of community relations and networks in maintaining peace (Colletta and Cullen 2000; Varshney 2002). Evidence on community relations during conflict is less readily available. Some studies have shown how community relations and norms strengthen during the conflict (Wickham-Crowley 1992; Petersen 2001). These effects may create important community ties to cope (and perhaps avoid) violence, but may also (re)enforce some forms of social capital that either feed into the conflict itself or may constitute the 'tipping point' for the outbreak of violence. ${ }^{12}$

Similar effects take place amongst displaced populations. Community networks are fundamental in facilitating the transition of people to new locations. But displacement into areas where productive activities cannot be accessed may also trap households in criminal and violent networks, or in semi-legal and illegal forms of activity (Moser and Mcllwaine 2004; Salehyan and Gleditsch 2006; Steele 2007). The economic outcome of these changes is unclear as few studies reflect on the impact caused by the transformation of social

\footnotetext{
11 See Brück (2004) and McKay and Loveridge (2005) for analyses of the impact of subsistence agriculture on household welfare in post-conflict settings.

12 This argument is illustrated in Petersen (2001) and Pinchotti and Verwimp (2007). Kalyvas (2007: 14) refers to these important community-level effects as the 'dark side of social capital'.
} 
relations, and the formation of new alliances and networks, on the economic status of households in conflict areas.

\subsection{Indirect impact of violence on political institutions}

Armed conflicts change the structure of political institutions, both local and national, and their relationship with populations. These changes are likely to impact on the economic well-being of households in conflict areas through changes in the ability of political institutions to provide public goods, physical security and the protection of property rights. Households that are more vulnerable to economic decline and whose members are more likely to be targets of violence will be badly affected by these changes.

But violent conflict also offers important opportunities for new local leaders to challenge old political powers and for local alternative governance structures to emerge in places where the state is absent (either before the conflict or due to the loss of territorial control during the conflict) (Arjona and Kalyvas 2006; Kalyvas 1999; Reno 2002; Valentino 2004). The impact of these forms of political transformation and power competition on the economic status of individuals and households is unclear. Organisations that favour corrupt, rent-seeking and destructive behaviour will perpetuate dysfunctional economic, social and political relations (Sánchez and Palau 2006). Organisations that during and after the conflict promote the rule of law, enforce appropriate norms of conduct and impose sanctions for undesirable behaviour may improve the living conditions of households under their control (Arjona and Kalyvas 2006; Bellows and Miguel 2006; Olson 2000; Weinstein 2007).

\subsection{Indirect impact of violence on economic growth and distribution}

The direct and indirect effects of violent conflicts can be made more or less acute through changes in overall economic growth and the distribution of national incomes. Violent conflicts have been one of the most significant causes of growth decline in modern economies (Collier $1999,2007)$, through the damage they cause to infrastructure, markets and social cohesion, and their effects on the capacity of economies and households to respond to other shocks (Rodrik 1998; Binzel and Brück 2006; Brück and Schindler 2007). These effects may be sufficient to drive many poor households into forms of poverty traps, and to push households that were relatively well-off at the start of the conflict into poverty. This may in turn reinforce the mechanisms that triggered conflict and violence in the first place, or create new incentives for violence (see Cárdenas 2002).

Notably, armed conflict may well result in the exclusion of certain groups from social, economic and political opportunities. A large literature has examined the impact of inequalities on the onset of civil conflict (see, for instance, Esteban and Ray 1994; Muller and Seligson 1987; Østby 2006). Much less exists on the impact of conflict on distributional arrangements in societies affected by violence, ${ }^{13}$ though emerging literature shows evidence for a readjustment in not only in the distribution of national incomes but also in sub-national patterns of distribution that may have considerable implications for economic policies in the post-conflict period (see Addison and Brück 2008). 


\section{Household adaptation strategies and the duration of violent conflicts}

The analysis in the section above illustrated how the exposure of households and individuals to violence during the conflict affects their economic status. In some cases, these effects can be severely damaging. In others, the benefits from violent conflict may be substantial. In general, this net impact will depend on the capacity of households to adapt to changing economic, social and political circumstances throughout the conflict.

Households living in risky environments tend to develop a complexity of (ex ante) riskmanagement and (ex post) risk-coping strategies. ${ }^{14}$ Although there is currently little understanding of differences between war-time and post-war coping strategies of households, accumulating evidence suggests that most known strategies will be considerably restricted during violent conflict (see Azam, Collier and Cravinho 1994; Bundervoet 2006; de Walque 2004; Ibáñez and Moya 2006; Verpoorten 2003, 2005). As a result, initial outbreaks of conflict are likely to create a cycle of conflict and poverty traps from which households are not able to escape easily (Collier 2007; Justino 2008a).

There are nonetheless plenty of accounts of people's economic and social ingenuity and resilience in contexts of enduring violence. Many households leave areas of more intense fighting to refugee and displacement camps, migrate to safer urban areas or move abroad. But numerous households live in conflict areas and survive (see Wood 2003; Steele 2007). They do so by integrating themselves (voluntarily or reluctantly) within social and political alliances that form locally and new forms of (legal and illegal) economic exchange. Often this involves participating and supporting armed groups through the provision of soldiers, shelter, food and information. This mechanism is represented by the double lines in Figure 2.1 (p. 10).

In order to avoid destitution, households unable to move from areas of conflict (or that choose to remain in areas of conflict for economic, religious, cultural or ideological reasons) resort to armed groups to protect their economic status in times of violence. Some recent literature has shown evidence on how local populations coexist with armed groups in the same areas, despite the occurrence of fighting, including how local armed groups provide employment to younger household members (Humphreys and Weinstein 2008), facilitate access to land (Wood 2003), allow small businesses and cultivation of land to continue to operate (Steele 2007), offer physical protection from violence (Kalyvas and Kocher 2007) and are able to access better information about the activities of opposing armed groups (often through the networks formed by their civil support groups) (Kalyvas 2007; Weinstein 2007). In some circumstances, particularly when the state is absent, local armed groups may establish social norms and provide public goods and physical security (see Arjona and Kalyvas 2006; Kalyvas 1999).

Armed groups in turn make use of different levels of support from local populations to advance their strategic objectives, particularly when other resources are scarce (see Weinstein 2007). The higher the level of participation and support for armed groups, the more likely the strategic objectives of armed group are to succeed during and after the conflict. Participation and support of ordinary citizens provides therefore an explanation for the (short or long) duration of armed conflicts because it determines to a large extent the strength of armed groups. 
However, not all households and individuals support and participate in armed groups or provide recruits, even in areas controlled by the group, and despite the presence of the various incentives before and during the conflict as discussed in the beginning of the paper (see, for instance, Wood 2003). What then makes some households and their members participate? The next section proposes and discusses a theoretical framework to understand individual and household participation and support for armed groups in conflict areas grounded in economic motivations.

\section{Framework for the analysis of individual and household participation in armed groups}

The analysis in the two previous sections suggests that participation is a function of two interdependent variables. The first is initial household characteristics, which determine the extent of the household's vulnerability to poverty. The second is the extent of the exposure of the household to violence during conflict or, in other words, its vulnerability to violence. The interaction between these two variables determines the probability of a given household (or its members) participating in and supporting armed groups due to their effects on the costs of participation in relation to the costs of non-participation.

Initial household characteristics, including its economic position, composition, ethnicity, religion and location, are important determinants of how households adapt to violent conflict. In particular, and keeping all other characteristics fixed, initial asset endowments held by the household will determine its capacity to draw on savings and accumulated assets when household members die or are injured, adapt to losses in productive assets or access new forms of livelihood in relocation areas. Households in possession of land holdings, livestock and savings may be able to use these to secure their access to food and credit and replace assets. Wealthier households will in principle be in a better position to protect themselves against the (negative) economic transformations associated with conflict. Poorer households face higher economic costs of non-participation due to both the high costs of staying neutral (for instance, access to land and markets may be further restricted) and the high costs of outside options (often they are not available). As a result, while keeping all other economic and non-economic characteristics fixed:

Hypothesis 1: The poorer the household is at the start of the conflict, the higher is the probability of the household participating and supporting an armed group.

This hypothesis is consistent with evidence that poorer individuals constitute the bulk of soldiers in armed groups (Humphreys and Weinstein 2008), that poor peasants participate in insurgencies (Scott 1976; Wood 2003), that patterns of displacement vary across individual economic status (Czaika and Kis-Katos 2007) and that price reductions in labour-intensive sectors (where most of the poor are employed) encourage conflict through increases in incentives for mobilisation because they lower the economic opportunity costs of participation (Dube and Vargas 2007). Hypothesis 1 does not imply that poverty amongst households and individuals will per se result automatically in a higher rate of participation in armed groups. But high vulnerability to poverty increases the risk of non-participation which in turn provides important mechanisms whereby armed groups can extend their support basis, recruit fighters and agree on forms of reciprocity with civilians in areas they wish to control.

Households that are poorer at the start of the conflict do not necessarily have to be the worst affected by the direct and indirect impacts of violence since better-off households may be characterised by particular features that may make them more prone to violence. This leads to the second condition for household participation in armed groups: their level of 
vulnerability to violence. This condition refers to the specific characteristics of households and their members that may make them more prone to being a target of violence, being recruited into fighting units or being forced to leave their area of residence. These characteristics may have to do with identifiable forms of group membership (for instance, being from a certain race or ethnic or religious group or subscribing specific ideologies), geographic location (such as living in areas of combat or 'being in the wrong place at the wrong time') or may be economic (for instance, holding property and other assets coveted by fighting units). ${ }^{15}$

The advantages or disadvantages of initial economic characteristics may be emphasised by the conflict itself. Economic elites may reinforce their economic, social and political position if the faction they support wins the conflict, or if they are able to isolate themselves and their property abroad and away from destruction. Poorer households, on the other hand, may become even worse-off when access to markets and informal networks becomes restricted and local forms of governance reinforce previous injustices and economic disparities. However, the advantages and disadvantages of initial characteristics may be overhauled by the exposure of the household to violence. Wealthier households may lose their initial economic advantage when their property is looted or destroyed, whereas poorer households may gain from economic, social or political connections with armed groups. As demonstrated in Kalyvas (2007) and Kalyvas and Kocher (2007), high risk of exposure to violence from one armed group will increase the probability of a household and its members supporting and participating in the opposing group. This evidence allows us to derive the following hypothesis:

Hypothesis 2: The higher the risk of violence, the higher is the probability of the household participating and supporting an armed group.

Although the initial characteristics that make households vulnerable to poverty and violence may arguably be largely immutable, the levels of vulnerability of a specific household may evolve during the conflict in response to the economic, social and political transformations that take place locally, in particular, the forms of community alliances that are formed and the types of governance and organisation of violence exercised by the armed group in command of the area of residence of the household. These structures depend on the type and intensity of violence, notably selective or indiscriminate violence (Kalyvas 2007), the level of control exercised in the territory by each armed group (Kalyvas 2007), and the physical and human resources and technology available to armed groups (Weinstein 2007). We would expect that the higher the level of control exercised by the armed group and the higher the resources available locally, the higher is the probability that a given household living in the area will participate in and collaborate with the armed group. This is due to three factors. First, the armed group will be in a better position to provide the resources needed to avoid poverty and destitution. Second, violence (in particular indiscriminate violence) is likely to decrease with levels of territorial and resource control (Kalyvas 2007). And thirdly, high levels of control and access to local resources (including a large population support basis) are more likely to result in forms of 'stationary banditry' where the provision of security, welfare and norms of behaviour may promote better living conditions amongst the population (Arjona and Kalyvas 2006).

The hypotheses above suggest how in general the levels of household vulnerability to poverty and vulnerability to violence affect the probability of household participation in any armed group during conflict. Let us now envisage a situation where an armed group takes over the control of one specific community. Some households (or their members) will stay

\footnotetext{
15 Justino and Verwimp (2006) and Verwimp (2005) show that households that were land-rich and non-poor in 1990 were the worst affected during the 1994 Rwandan genocide. The concept of vulnerability to violence is also explored in Verwimp (2008). See in addition Binzel and Brück (2006) and Brück and Schindler (2007) on the relationship between conflict and fragility.
} 
and participate, some may stay and remain neutral and some may move. What determines each option? The interaction between the levels of household vulnerability to poverty and violence should result in four distinct scenarios. Each scenario results in several testable hypotheses about household participation in local armed groups, which are outlined in Table 4.1.

Table 4.1 Participation in armed groups

\begin{tabular}{|c|c|c|}
\hline & High vulnerability to violence & Low vulnerability to violence \\
\hline $\begin{array}{l}\text { High } \\
\text { vulnerability } \\
\text { to poverty }\end{array}$ & $\begin{array}{l}\text { Scenario A: } \\
\text { A.1. Probability of participation increases with levels } \\
\text { of violence from opposing armed group and for } \\
\text { lower levels of asset availability and fewer livelihood } \\
\text { options } \\
\text { A.2. Probability of remaining in area and staying } \\
\text { neutral is negligent } \\
\text { A.3. Probability of moving increases with levels of } \\
\text { violence from local armed group }\end{array}$ & $\begin{array}{l}\text { Scenario B: } \\
\text { B.1. Probability of participation increases for lower } \\
\text { levels of asset availability and fewer livelihood options } \\
\text { B.2. Probability of staying neutral is negligent but may } \\
\text { increase for higher levels of asset availability and } \\
\text { larger livelihood options } \\
\text { B.3. Probability of moving is negligent }\end{array}$ \\
\hline $\begin{array}{l}\text { Low } \\
\text { vulnerability } \\
\text { to poverty }\end{array}$ & $\begin{array}{l}\text { Scenario C: } \\
\text { C.1. Probability of participation increases with levels } \\
\text { of violence from opposing armed group and if } \\
\text { economic benefits from local group are high } \\
\text { C.2. Probability of staying neutral increases if } \\
\text { benefits from participation are low } \\
\text { C.3. Probability of moving (or migrating) increases } \\
\text { with levels of violence from local armed group and if } \\
\text { benefits from participation are low }\end{array}$ & $\begin{array}{l}\text { Scenario D: } \\
\text { D.1. Probability of participation is negligent unless } \\
\text { strong level of initial support for armed group or } \\
\text { sources of wealth cannot be moved } \\
\text { D.2. Probability of staying neutral increases if benefits } \\
\text { from participation are low } \\
\text { D.3. Probability of moving increases if costs of staying } \\
\text { are high (e.g. level of destruction of infrastructure and } \\
\text { institutions) and if benefits from participation are low }\end{array}$ \\
\hline
\end{tabular}

The first scenario $(A)$ includes households that are highly vulnerable to both poverty and violence. These are, for instance, poor households that belong to particular ethnic and religious groups or poor households with large numbers of young males (and hence valuable as a source of fighters). These households will participate if they are targets of violence by outside armed groups (for instance, due particular ethnic characteristics) as local armed groups may be able to protect them against external forms of selective violence and possibly against extreme forms of destitution that they would experience in camps. If the violence is exercised by the armed group controlling the area, those that can escape persecution will flee to refugee or IDP camps. ${ }^{16}$

Scenario B includes households that are vulnerable to poverty but experience low vulnerability to violence (for instance, poor households with few assets that can be looted, belonging to the 'right' ethnic group or living outside the worst combat zones). These households will generally stay in areas of residence as the economic costs of nonparticipation may be too high. These are households with few possessions or accumulated wealth. If they hold some land and are allowed to keep it and cultivate it, they may stay neutral. For those with lower assets, the participation and support for local armed group may well increase substantially their chances of avoiding famine and destitution. Ideological support and common forms of cultural identification may reinforce the likelihood of participation (see Gates 2002).

The third scenario $(C)$ refers to households that experience low vulnerability to poverty and high vulnerability to violence. These households have higher outside options than those in

16 Populations may also flee if displacement is used as a deliberate strategy by armed groups trying to control territories and resources. In this case the armed group will value less their population support bases and the mechanisms outlined in this paper may not work. This often happens when armed groups benefit from extensive external military and financial support or plan to finance their activities through the forceful appropriation of natural or agricultural resources (Weinstein 2007). But even in these cases the armed group may reverse their displacement strategy when eventually they will need labour to operate mines and oil fields, or to cultivate (illegal) crops or when external support becomes no longer available. 
scenario A. They face high exposure to violence (probably because they hold desirable property or assets or belong to certain ethnic or ideological groups) but may have enough accumulated wealth that allows to them to pursue alternative coping strategies. If the violence they face is from the local armed group, those that survive or are able to anticipate well in advance the breakout of violence will move to more secure areas. This may include migration to another country if movements abroad are still possible, which may explain the presence of wealthy political refugees abroad and other forms of economic migration from conflict areas. If the violence is from outside armed groups, households in scenario C may participate. Because these households have some outside options, they will participate (instead of staying neutral or leaving) when the economic and security benefits offered from the armed group outweigh outside options. ${ }^{17}$ Households that have accumulated wealth in the form of land may stay behind. Households in possession of more liquid assets may be able to move them to safer areas.

The final scenario (D) includes households that exhibit low vulnerability to both poverty and violence. Unless there are considerable constraints to population movements, these households have a reasonable large range of choices available to them. These are also valuable households to armed groups. They are likely to exhibit the 'right' ethnic, economic, ideological and political characteristics and possess accumulated wealth. Provided that they do not get abducted or forced in any other way to remain in the area of control of the armed group, these households will generally depart if they fear for their possessions and local levels of infrastructure and institutional destruction were high or may stay neutral when they have little to gain from participation. They will participate if they were supporters of the armed group to begin with (for ideological or other reasons), if their sources of wealth cannot be easily moved (for instance, they own land) or if the operation of their businesses is dependent on participation.

\section{Conclusion and implications}

This paper proposed an analytical framework to understand important endogenous links between household poverty and armed conflict that impact on the level of participation and support of individuals and households in conflict areas for armed groups. Individuals and households in conflict areas provide human and material resources, shelter and information to armed groups because often this is often the only way they have of protecting them and their families from misery and destitution, as well as death, injury and imprisonment. These decisions offer an important, even if partial, explanation for the outbreak, recurrence and duration of warfare because they determine the strength of armed groups and the feasibility of their strategies before and during the conflict.

This analysis has empirical and policy implications. Despite a recent welcoming surge in empirical micro-level research, ${ }^{18}$ we still lack considerable evidence on fundamental processes linking armed civil conflict and household welfare. ${ }^{19}$ The general validation of the analytical framework and refinement of the hypothesis discussed in the paper requires serious advances in building empirical bases for linking factors that affect the viability of violent conflicts to household behaviour and the socio-economic preferences of households and their individual members. This is a challenging but not impossible task given the recent

\footnotetext{
17 Lower economic benefits from participation may also be compensated by ideological motivations as discussed in Gates (2002)

18 See MICROCON (www.microconflict.eu), Households in Conflict Network (www.hicn.org), Program on Order, Conflict and Violence at Yale University (www.yale.edu/macmillan/ocvprogram/index.html), Centre for Research on Inequality, Human Security and Ethnicity (www.crise.ox.ac.uk) and Survey of War Affected Youth (www.sway-uganda.org). 
improvements in data availability and in analytical qualitative and quantitative methods. We expect the framework proposed in this paper to act as a benchmark for further empirical work on the analysis of the relationship between armed conflict and household welfare. Interesting further extensions to this paper include more detailed theoretical and empirical distinctions between types and levels of violence, different forms of rebel organisation, different levels and forms of participation and different household preferences and participation cost structures.

In policy terms, it seems unavoidable that the endogenous processes discussed in this paper will sustain and prolong armed conflicts unless the conditions for household and individual support of armed groups are eliminated, or at least significantly weakened, by external intervention. A large literature already exists on the design of international and national-level policies to end violent conflict and eliminate the risk of renewed fighting (see Weinstein 2007 and Justino 2008a, 2008b for reviews). Much less attention has been paid to the role played by ordinary citizens in violent conflicts (beyond relief programmes for victims of violence). Actions aimed at ending armed conflict call for efforts not only to reinforce state capacity and eliminate resources available to armed groups, but also to address the effects of their human support basis either as a source of conflict re-ignition or, in cases where the conflict served to establish more legitimate forms of state- and nation-building, to promote the legitimacy of new political, economic and social institutions. In either case, policies must focus on strengthening the economic lives of those living in conflict areas, keeping in mind the strong association between household and individual economic status and the social, economic and political transformations entailed by the conflict itself. 


\section{References}

Addison, T. and Brück, T. (2008) Making Peace Work: The Challenges of Social and Economic Reconstruction, London: Palgrave Macmillan

Alderman, H.; Hoddinott, J. and Kinsey, B. (2006) 'Long Term Consequences of Early Childhood Malnutrition', Oxford Economic Papers 58.3: 450-74

Arjona, A.M. and Kalyvas, S.N. (2006) 'Preliminary Results of a Survey of Demobilized Combatants in Colombia', unpublished manuscript, Yale University, http://research.yale.edu/stathis/documents/Report5-06.pdf (accessed 8 December 2011)

Azam, J-P. (2006) 'On Thugs and Heroes: Why Warlords Victimize Their Own Civilians', Economics and Governance 7.1: 53-73

Azam, J-P.; Collier, P. and Cravinho, A. (1994) 'Crop Sales, Shortages and Peasant Portfolio Behaviour: An Analysis of Angola', Journal of Development Studies 30.2: 361-79

Becker, G.S. (1967) 'Crime and Punishment: An Economic Approach', Journal of Political Economy 76.2: 169-217

Bellows, J. and Miguel, E. (2006) 'War and Institutions: New Evidence from Sierra Leone', American Economic Review 96.2: 394-9

Binzel, C. and Brück, T. (2006) 'Analyzing Conflict and Fragility at the Micro-Level', paper presented at the USAID-HiCN conference on Conflict and Fragility, Washington DC, 5-6 November

Bircan, C.; Brück, T. and Vothknecht, M. (2008) 'The Economic Effects of Conflict on Inequality', unpublished paper, DIW Berlin

Blattman, C. and Annan, J. (2007) The Consequences of Child Soldiering, HiCN Working Paper 22, Households in Conflict Network, www.hicn.org

Blattman, C. and Miguel, E. (2010) 'Civil War', Journal of Economic Literature 48.1: 3-57

Brockett, C.D. (1990) Land, Power, and Poverty: Agrarian Transformation and Political Conflict in Central America, Boston: Unwin Hyman

Brück, T. (2004) The Welfare Effects of Farm Household Activity Choices in Post-War Mozambique, HiCN Working Paper 04, Households in Conflict Network, www.hicn.org

Brück, T. and Schindler, K. (2007) 'The Impact of Conflict: A Conceptual Framework with Reference to Widow and Refugee Households', paper presented at the second annual workshop of the Household in Conflict Network, Antwerp, 19-20 January

Brückner, M. and Ciccone, A. (2007) Growth, Democracy, and Civil War, Working Paper 1053, Department of Economics and Business, Universitat Pompeu Fabra, http://papers.ssrn.com/sol3/papers.cfm?abstract_id=1028221

Bueno de Mesquita, E. (2005) 'The Quality of Terror', American Journal of Political Science 49.3: $515-30$ 
Bundervoet, T. (2006) Livestock, Activity Choices and Conflict: Evidence from Burundi, HiCN Working Paper 24, Households in Conflict Network, www.hicn.org

Bundervoet, T. and Verwimp, P. (2005) Civil War and Economic Sanctions: An Analysis of Anthropometric Outcomes in Burundi, HiCN Working Paper 11, Households in Conflict Network, www.hicn.org

Cárdenas, M. (2002) ‘Economic Growth in Colombia: A Reversal of 'Fortune?”, unpublished manuscript, Center for International Development, Harvard University, www.cid.harvard.edu/cidwp/083.htm

Centre for Poverty Analysis (2006) Moving Out of Poverty in Conflict-Affected Areas in Sri Lanka, Country Synthesis Report for the Moving Out of Poverty Study, Centre for Poverty Analysis, Sri Lanka

Chronic Poverty Research Centre (2005) Chronic Poverty Report 2004-2005, University of Manchester

Colletta, N.J. and Cullen, M.L. (2000) Violent Conflict and the Transformation of Social Capital: Lessons from Cambodia, Rwanda, Guatemala, and Somalia, Conflict Prevention and Post-Conflict Reconstruction, Washington DC: World Bank

Collier, P. (2007) The Bottom Billion: Why the Poorest Countries Are Failing and What Can Be Done About It, Oxford: Oxford University Press

_ (1999) 'On the Economic Consequences of Civil War', Oxford Economic Papers 50.4: 168-83

Collier, P. and Hoeffler, A. (2004) 'Greed and Grievance in Civil War', Oxford Economic Papers 56.4: 563-95

_ـ (1998) 'On Economic Causes of Civil War', Oxford Economic Papers 50.4: 563-73

Collier, P.; Hoeffler, A. and Söderbom, M. (2004) 'On the Duration of Civil War', Journal of Peace Research 41.3: 253-73

Collier, P.; Elliot, V.L.; Hegre, H.; Hoeffler, A; Reynal-Querol, M. and Sambanis, N. (2003) Breaking the Conflict Trap: Civil War and Development Policy, Oxford: Oxford University Press

Czaika, M. and Kis-Katos, K. (2007) Civil Conflict and Displacment: Village-Level Determinants of Forced Migration in Aceh, HiCN Working Paper 32, Households in Conflict Network, www.hicn.org

de Walque, D. (2004) The Long-Term Legacy of the Khmer Rouge Period in Cambodia, World Bank Policy Research Working Paper 3446, Washington DC: World Bank, http://papers.ssrn.com/sol3/papers.cfm?abstract_id=625324

Do, Q.T. and lyer, L. (2007) Poverty, Social Divisions, and Conflict in Nepal, HBS Finance Working Paper 07-065, Harvard Business School, http://hbswk.hbs.edu/item/5669.html

Doyle, M. and Sambanis, N. (2006) Making War and Building Peace: United Nations Peace Operations, New York: Princeton University Press 
Dube, O. and Vargas, J. (2007) Are All Resources Cursed? Coffee, Oil and Armed Conflict in Colombia, Working Paper 2007-1, Weatherhead Center for International Affairs, Harvard University

Durlauf, S.N. (2006) 'Groups, Social Influences and Inequality', in S. Bowles, S.N. Durlauf and K. Hoff (eds), Poverty Traps, Princeton University Press

Elbadawi, I. and Sambanis, N. (2002) 'How Much War Will We See? Explaining the Prevalence of Civil War', Journal of Conflict Resolution 46.3: 307-34

_ (2000) 'Why Are There So Many Civil Wars in Africa: Understanding and Preventing Violent Conflict', Journal of Peace Research 9.3: 244-69

Engel, S. and Ibáñez, A.M. (2007) 'Displacement Due to Violence in Colombia: A HouseholdLevel Analysis', Economic Development and Cultural Change 55.2: 335-65

Esteban, J. and Ray, D. (1994) 'On the Measurement of Polarization', Econometrica 62.4, 819-52

Fafchamps, M. and Lund, S. (2002) 'Risk-Sharing Networks in Rural Philippines', Journal of Development Economics 71.2: 261-87

Fearon, J.D. (2004) 'Why Do Some Civil Wars Last So Much Longer Than Others?', Journal of Peace Research 41.3: 275-301

Fearon, J.D. and Laitin, D. (2003) 'Ethnicity, Insurgency and Civil War', American Political Science Review 97.1: 75-90

Gates, S. (2002) 'Recruitment and Allegiance: The Microfoundations of Rebellion', Journal of Conflict Resolution 46.1: 111-30

Ghobarah, H.A.; Huth, P and Russett, B. (2003) 'Civil Wars Kill and Maim People - Long After Shooting Stops', American Political Science Review 97.2: 189-202

Goodwin, J. (2001) No Way Out: States and Revolutionary Movements 1945-1991, Cambridge Studies in Comparative Politics, Cambridge: Cambridge University Press

Grossman, H.I. (2002) 'Make Us a King: Anarchy, Predation, and the State', European Journal of Political Economy 18.1: 31-46

Gurr, T.R. (1970) Why Men Rebel, New York: Princeton University Press

Hegre, H. and Sambanis, N. (2006) 'Sensitivity Analysis of Empirical Results on Civil War Onset', Journal of Conflict Resolution 50.4: 508-35

Hirshleifer, J. (2001) The Dark Side of the Force: Economic Foundations of Conflict Theory, Cambridge: Cambridge University Press

Horowitz, D. (1985) Ethnic Groups in Conflict, Berkeley: University of California Press

Humphreys, M. (2005) 'Natural Resources, Conflict, and Conflict Resolution: Uncovering the Mechanisms', Journal of Conflict Resolution 49.4: 508-37

Humphreys, M. and Weinstein, J. (2008) 'Who Fights? The Determinants of Participation in Civil War', American Journal of Political Science 52.2: 436-55 
Ibáñez, A.M. and Moya, A. (2006) The Impact of Intra-State Conflict on Economic Welfare and Consumption Smoothing: Empirical Evidence for the Displaced Population in Colombia, HiCN Working Paper 23, Households in Conflict Network www.hicn.org

Justino, P. (2008a) 'A Micro Level Analysis of Poverty and Conflict Traps', unpublished manuscript, Harvard University

- (2008b) The Impact of Armed Civil Conflict on Household Welfare and Policy Responses, background paper for the World Economic and Social Survey 2008, United Nations

_ (2006) 'The Impact of Collective Action on Economic Development: Empirical Evidence from Kerala, India', World Development 34.7: 1254-70

Justino, P. and Shemyakina, O. (2007) 'Private and Public Transfers as a Coping Strategy under Armed Conflict: the Case of Tajikistan', paper presented at the Third Annual Workshop of the Households in Conflict Network, IDS, Brighton, 10-11 December

Justino, P. and Verwimp, P. (2006) Poverty Dynamics, Conflict and Convergence in Rwanda, HiCN Working Paper 16, Households in Conflict Network, www.hicn.org

Kalyvas, S.N. (2007) The Logic of Violence in Civil Wars, Cambridge: Cambridge University Press

— (1999) 'Wanton and Senseless? The Logic of Massacres in Algeria', Rationality and Society 11.3: 243-85

Kalyvas, S.N. and Kocher, M. (2007) 'How "Free” is Free-Riding in Civil Wars?', World Politics 59.2: 177-216

Keen, D. (2005) Conflict and Collusion in Sierra Leone, London: James Currey Publishers

- (1998) The Economic Functions of Violence in Civil Wars, Adelphi Paper 320, Oxford: International Institute of Strategic Studies

Kondylis, F. (2007) Agricultural Outputs and Conflict Displacement: Evidence from a Policy Intervention in Rwanda, HiCN Working Paper 28, Households in Conflict Network, www.hicn.org

_ (2005) 'Agricultural Production and Conflict Refugee Status: Quasi-Experimental Evidence from a Policy Intervention Programme in Rwanda', unpublished manuscript, Economics Department, Royal Holloway, University of London

Krueger, A.B. and Malečková, J. (2003) ‘Education, Poverty and Terrorism: Is There a Causal Connection?', Journal of Economic Perspectives 17.4: 119-44

Lacina, B. and Gleditsch, N.P. (2005) 'Monitoring Trends in Global Combat: A New Dataset of Battle Deaths', European Journal of Population 21.2-3: 145-66

Lichbach, M. (1995) The Rebel's Dilemma, Ann Arbor: University of Michigan Press

Lindley, A. (2007) Remittances in Fragile Settings: A Somali Case Study, HiCN Working Paper 27, Households in Conflict Network, www.hicn.org 
Matijasevic, M.T.; Velásquez, L.; Villada, C. and Ramírez, M. (2007) Moving Out of Poverty: Understanding Freedom, Growth and Democracy from the Bottom-Up - National Synthesis Report, Colombia, Centro de Estudios Regionales Cafeteros y Empresariales, Manizales, Colombia

McKay, A. and Loveridge, S. (2005) Exploring the Paradox of Rwandan Agricultural Household Income and Nutritional Outcomes in 1990 and 2000, Staff Paper 2005-06, Department of Agricultural Economics, Michigan State University, Michigan, http://ageconsearch.umn.edu/bitstream/11582/1/sp05-06.pdf

Miguel, E.; Satyanath, S. and Sergenti, E. (2004) 'Economic Shocks and Civil Conflict: An Instrumental Variables Approach,' Journal of Political Economy 112.4: 725-53

Moser, C. and Mcllwaine, C. (2004) Encounters with Violence in Latin America: Urban Poor Perceptions from Colombia and Guatemala, London: Routledge

Muller, E.N. and Seligson, M.A. (1987) 'Inequality and Insurgency', American Political Science Review 81.2: 425-51

Murshed, M. and Gates, S. (2005) 'Spatial-Horizontal Inequality and the Maoist Insurgency in Nepal', Review of Development Economics 9.1: 121-34

Olson. M. (2000) Power and Prosperity: Outgrowing Communist and Capitalist Dictatorships, New York: Basic Books

_ (1965) The Logic of Collective Action: Public Good and the Theory of Groups, Cambridge MA: Harvard University Press

Østby, G. (2006) Horizontal Inequalities, Political Environment and Civil Conflict: Evidence from 55 Developing Countries, CRISE Working Paper 28, University of Oxford, www.crise.ox.ac.uk/pubs/workingpaper28.pdf

Paige, J. (1975) Agrarian Revolutions, New York: Free Press

Petersen, R. (2001) Resistance and Rebellion: Lessons from Eastern Europe, Cambridge: Cambridge University Press

Pinchotti, S. and Verwimp, P. (2007) Social Capital and the Rwandan Genocide: A MicroLevel Analysis, HiCN Working Paper 30, Households in Conflict Network, www.hicn.org

Reno, W. (2002) 'The Politics of Insurgency in Collapsing States', Development and Change 33.5: $837-58$

Richards, P. (1996) Fighting for the Rainforest: War, Youth and Resources in Sierra Leone, London: James Currey Publishers

Rodrik, D. (1998) Where Did All the Growth Go? External Shocks, Social Conflict, and Growth Collapses, NBER Working Paper 6350, Washington DC: National Bureau of Economic Research, www.nber.org/papers/w6350.pdf

Rosenzweig, M. and Wolpin, K. (1993) 'Credit Market Constraints and the Accumulation of Durable Production Assets in Low-Income Countries: Investments in Bullocks', Journal of Political Economy 101.2: 223-44 
Ross, M. (2006) 'A Closer Look at Oil, Diamonds, and Civil War', Annual Review of Political Science 9: 265-300

_ (2004) 'What Do We Know About Natural Resources and Civil War?', Journal of Peace Research 41.3: 337-56

Salehyan, I. and Gleditsch, K.S. (2006) 'Refugees and the Spread of Civil War', International Organization 60.2: 335-66

Sánchez, F. and Palau, M. (2006) Conflict, Decentralisation and Local Governance in Colombia, 1974-2004, HiCN Working Paper 14, Households in Conflict Network, www.hicn.org

Scott, J. (1976) The Moral Economy of the Peasant: Rebellion and Subsistence in Southeast Asia, New Haven: Yale University Press

Shemyakina, O. (2006) The Effect of Armed Conflict on Accumulation of Schooling: Results from Tajikistan, HiCN Working Paper 12, Households in Conflict Network, www.hicn.org

Singh, I.; Squire, L. and Strauss, J. (1986) Agricultural Household Models: Extensions, Applications and Policy, Baltimore: Johns Hopkins University Press

Steele, A. (2007) Massive Civilian Displacement in Civil War: Assessing Variation in Colombia, HiCN Working Paper 29, Households in Conflict Network, www.hicn.org

Stewart, F. and Fitzgerald, V. (2001) 'Introduction: Assessing the Economic Costs of War', in F. Stewart, V. Fitzgerald and Associates (eds), War and Underdevelopment. Volume 1: The Economic and Social Consequences of Conflict (1-20), Oxford: Oxford University Press

Tolman, R. and Raphael, J. (2000) 'A Review of the Research on Welfare and Domestic Violence', Journal of Social Issues 56.4: 655-82

Townsend, R.M. (1994) 'Risk and Insurance in Village India', Econometrica 62.3: 539-91

UNHCR, various years, UNHCR Global Report, New York: United Nations Refugee Agency

Valentino, B. (2004) Final Solutions: Mass Killing and Genocide in the 20th Century, Ithaca: Cornell University Press

Varshney, A. (2002) Ethnic Conflict and Civic Life: Hindus and Muslims in India, London: Yale University Press

Verpoorten, M. (2005) 'Self-Insurance in Rwandan Households: The Use of Livestock as a Buffer Stock in Times of Violent Conflict', unpublished manuscript, KU Leuven, Belgium

_ (2003) 'The Determinants of Income Mobility in Rwanda, 1990-2002', unpublished manuscript, KU Leuven, Belgium

Verwimp, P. (2008) Vulnerability to Conflict: A Micro-Perspective, Households in Conflict Network Research Design Note 7, www.hicn.org/research_design/rdn7.pdf

- (2005) 'An Economic Profile of Peasant Perpetrators of Genocide: Micro-Level Evidence from Rwanda', Journal of Development Economics 77.2: 297-323 
Walter, B.F. (2004) ‘Does Conflict Beget Conflict? Explaining Recurring Civil War', Journal of Peace Research 41.3: 371-88

Weinstein, J. (2007) Inside Rebellion: The Politics of Insurgent Violence, Cambridge: Cambridge University Press

Wickham-Crowley, T. (1992) Guerrillas and Revolution in Latin America: A Comparative Study of Insurgents and Regimes Since 1956, Princeton: Princeton University Press

Wood, E.J. (2003) Insurgent Collective Action and Civil War in El Salvador, Cambridge Studies in Comparative Politics, New York: Cambridge University Press

World Bank (2005) Toward a Conflict-Sensitive Poverty Reduction Strategy: Lessons from a Retrospective Analysis, World Bank Report 32587, Washington DC: The World Bank 